\title{
PERENCANAAN ANGKUTAN ANTAR JEMPUT SEKOLAH DASAR NEGERI 06 DAN 07 DI BEKASI
}

\author{
Widorisnomo, SH,MT \\ Dosen STTD \\ Jl. Raya Setu No. 89, Bekasi \\ Telp./Fax : (021) 8254640 \\ Drs. Eko Sudriyanto, MM \\ Dosen STTD \\ Jl. Raya Setu No. 89, Bekasi \\ Telp./Fax : (021) 8254640
}

\author{
Budiharso Hidayat, ATD,MT \\ Dosen STTD \\ Jl. Raya Setu No. 89, Bekasi \\ Telp./Fax : (021) 8254640
}

\author{
Eddi, S.sos, MM
}

Dosen STTD

Jl. Raya Setu No. 89, Bekasi

Telp./Fax : (021) 8254640

\begin{abstract}
In general, safety has not been felt by the community, this can be seen with many parents who take children to leave and go home from school. Children who are escorted and picked up when leaving and returning to school are generally those who study in Elementary School. students in elementary schools some students still go to / from school are still using motorbikes, delivered by parents either by motorbike or car or by shuttle with school vehicles. This condition raises traffic activity in addition to increasing traffic flow. This is because schools have not provided sufficient parking facilities. Therefore, in an effort to reduce accidents that mainly affect children because child safety is a shared responsibility between parents and the school. The government and the community must work hand in hand in providing and / or creating protection for children's safety in past activities. crossing.
\end{abstract}

Keywords: Transport Planning, school pick-up, safety

\begin{abstract}
Abstraksi
Secara umum keselamatan belum dirasakan masyarakat, hal ini terlihat dengan banyak orang tua yang mengantar anak-anak berangkat dan pulang sekolah. Anak-anak yang diantar dan dijemput saat berangkat dan pulang sekolah umumnya mereka yang belajar di Sekolah Dasar. siswa pada sekolah dasar sebagian siswa masih ada yang ke/dari sekolah masih menggunakan sepeda motor, diantar oleh orangtua baik dengan sepeda motor maupun mobil atau dengan antar jemput dengan
\end{abstract}


kendaraan sekolah. Kondisi ini memunculkan aktivitas lalu lintas selain meningkatkan arus lalu lintas .Hal ini disebabkan sekolah belum menyediakan fasilitas parkir yang cukup. Oleh karena itu, dalam upaya mengurangi kecelakan yang terutama menimpa anak-anak karena keselamatan anak merupakan tanggung jawab bersama antara orang tua dan pihak sekolah.Pemerintah dan masyarakat harus saling bahu membahu dalam memberikan dan/atau menciptakan perlindungan terhadap keselamatan anak-anak dalam beraktivitas lalu lintas.

Kata Kunci : Perencanaan Angkutan, antar jemput sekolah, keselamatan

\section{PENDAHULUAN}

\section{LATAR BELAKANG PENELITIAN}

Tujuan lalu lintas yang selamat, tertib, lancar, aman dan nyaman belum sesuai dengan harapan. Secara umum keselamatan belum dirasakan masyarakat, hal ini terlihat dengan banyak orang tua yang mengantar anak-anak berangkat dan pulang sekolah. Anak-anak yang diantar dan dijemput saat berangkat dan pulang sekolah umumnya mereka yang belajar di Sekolah Dasar.

Salah satu permasalahan transportasi kota-kota besar di Indonesia antara lain adalah keselamatan dalam berlalulintas. Keselamatan pengguna jalan merupakan prioritas utama dalam manajemen dan rekayasa lalu lintas. Pengguna jalan ini salah satu diantaranya adalah siswa dengan maksud perjalanan khusus untuk belajar. Siswa sebagai generasi penerus bangsa diharapkan keberlangsungan agar terhindar atau menjadi korban kecelakaan.

\section{A. RUMUSAN MASALAH}

Masih banyaknya kendaraan pengantar siswa/i yang berhenti untuk mengantar dan menjemput menggunakan kendaraan pribadi terutama sepeda motor, sehingga berdampak pada menurunnya kapasitas jalan, menimbulkan kemacetan dan rawan 
kecelakaan.Disamping itu juga memunculkan konflik antara orang dengan kendaraan baik saat memasuki sekolah dan atau meninggalkan sekolah.

Pelayanan angkutan umum bagisiswa SD disamping kurang memenuhi aspek keselamatan dalam fasilitas dan sirkulasi disebabkan belum tersedia fasilitas pejalan kaki dan angkutan umum, juga banyaknya pengguna sepeda motor menimbulkan pertanyaan apakah jika dilayani moda antar-jemput siswa lebih efisien dibanding dengan penggunaan sepeda motor.

\section{A. METODOLOGI PENELITIAN}

Penelitian ini meliputi kegiatan mulai dari :

1) Observasi awal untuk mengenali lokasi sekolah dasar yang berada di ruas Jalan Raya Setu di wilayah Cibuntu, Cibitung, Bekasi;

2) Pengumpulan data Inventarisasi siswa dan orang tua siswa berkaitan denganasal atau tempat tinggal siswa dan latar belakang sosio-ekonomi orang tua siswa;

3) Pengumpulan data untuk preferensi berkaitan dengan karakteristik perjalanan sekolah, pemilihan moda, waktu perjalanan, lama menunggu/jemput, biaya perjalanan;

4) Analisis data;

5) Usulan PelayananAngkutan Antar Jemput Siswa.

\section{B. METODE PENGUMPULAN DATA}

\section{Data Inventarisasi Siswa}

Data sekunder yang berkaitan dengan alamat atau tempat tinggal siswa

\section{Wawancara Orang tua Siswa}

Wawancara orang tua siswa untuk mengumpulkan data berkaitan dengan :

a. Karakteristik pelaku perjalanan

b. Penggunaan moda/alat angkut untuk perjalanan

c. Alasan pemilihan moda 
d. Tujuan perjalanan

e. Waktu melakukan perjalanan

f. Biaya perjalanan jika disediakan angkutan antar jemput

\section{METODE ANALISIS}

Adapun analisis yang digunakan dalam penelitian ini adalah :

\section{Analisis Permintaan Perjalanan Sekolah}

\section{Penentuan Trayek/Rute}

. Tahapan-tahapan dalam perencanaan suatu rute adalah :
a. Identifikasi Asal-tujuan Perjalanan
b. Analisis Kondisi Prasarana Jaringan Jalan
c. Penentuan Koridor Daerah Pelayanan
d. Identifikasi Lintasan Rute
e. Analisis dan Penentuan Rute Terpilih

\section{Penentuan kebutuhan fasilitas angkutan umum}

Keberadaan lokasi penjemputan dan pengantaran untuk rencana pengoperasian angkutan ini sebagai tempat menaikkan dan menurunkan siswa dengan pendekatan :
a. Berada di sepanjang rute angkutan antar jemput;
b. Terletak pada jalur pejalan (kaki) dan dekat dengan fasilitas pejalan (kaki);
c. Diarahkan dekat dengan pusat kegiatan atau permukiman;
d. Dilengkapi dengan rambu petunjuk;
e. Tidak mengganggu kelancaran arus lalu-lintas.

\section{Pemilihan Moda}

\section{Rencana Operasional}

Rencana operasional meliputi analisis yang berhubungan dengan :

\section{Penentuan Rute}

2. Panjang Trayek 


\section{Kebutuhan Armada}

\section{Tarif}

\section{Penjadwalan}

\section{ANALISIS DATA}

\section{A. GAMBARAN LOKASI PENELITIAN}

\section{Karakteristik Guna Lahan}

Survai pengamatan lapangan dibutuhkan untuk memilih lokasi yang sesuai dengan hasil keluaran penelitian, karena tidak semua lokasi sekolah dapat dijadikan sebagai objek penelitian.Objek penelitian yang dibutuhkan dalam penelitian ini memiliki kriteria lokasi yang disesuaikan dengan klasifikasi yang dapat dikategorikan sebagai kawasan sekolah yang layak untuk dilakukan penerapan angkutan antar jemput sekolah.Jumlah siswa yang mengikuti pendidikan di Sekolah Dasar 6 dan 7 seluruhnya berjumlah 382 siswa $(152+230$ siswa).

Hasil inventarisasi kondisi kawasan sekolah dilaksanakan untuk mengetahui jenis guna lahan sekitar lokasi, posisi terhadap jaringan jalan dan fasilitas yang disediakan.Sekolah Dasar 6 dan 7 terletak pada Ruas Jalan Raya Setu Kampung Utan km 2,5 merupakan sekolah dasar yang menempati pada satu area secara bersama dengan luas $\left(3.562 \mathrm{~m}^{2}+1.500 \mathrm{~m}^{2}\right) 5.062 \mathrm{~m}^{2}$. Penggunaan lahan lahan pada kiri dan kanan ruas jalan ini adalah pemukiman, bengkel, fasilitas olah raga dan perkantoran.

Satu-satu ruas jalan yang menjadi akses menuju sekolah ini adalah ruas jalan raya Setu-Kampung Utan. Ruas jalan ini memiliki lebar lajur 3,6 dan 3,9 meter dengan type 2/2 UD. Ruas jalan ini tidak memiliki fasilitas pejalan kaki untuk menyusuri dan median sebagai pembatas jalan. Lebar bahu ruas jalan ini 0,6 meter pada sisi kiri (depan Sekolah Dasar) serta dilengkapi bahu jalan pada salah satu sisi lain (seberang jalan Sekolah Dasar) sebesar 1 meter. 


\section{Karakteristik Lalu Lintas}

\section{a. Volume lalu lintas}

Pencacahan lalu lintas terklasifikasi pada ruas jalan ini dilaksanakan mulai dari jam 05.00 - 22.00 WIB menunjukkan bahwa karakteristik lalu lintas pada lokasi ini saat pagi hari arus lalu lintas menuju Kampung Utan lebih tinggi dibanding menuju Setu. Arus lalu lintas menuju Kampung Utan pagi hari tertinggi mencapai 523 kendaraan/jam dan arah sebaliknya menuju ke Setu sebesar 306 smp/jam.

Pada ruas jalan di depan Sekolah Dasar 6 dan 7 Cibuntu yang menjadi obyek penelitian menunjukan bahwa waktu sibuk pagi terjadi pada 06.00 - 07.00 WIB dan sore hari pada 16.00 - 17.00 WIB. Kondisi lalu lintas yang berhubungan dengan aktivitas sekolah dasar pada waktu $06.00-$ 07.00 WIB dan siang hari pada 11.00 - 12.00 WIB menunjukkan bahwa arus lalu lintas mencapai $829 \mathrm{smp} / \mathrm{jam}$ dan $572 \mathrm{smp} / \mathrm{jam}$.

Kondisi arus lalu lintas pada lokasi hasil pengamatan di ruas jalan raya Setu - Kampung Utan atau depan lokasi sekolah dasar 6 dan 7 Cibuntu, Cibitung Bekasi dapat dilihat pada gambar berikut ini.

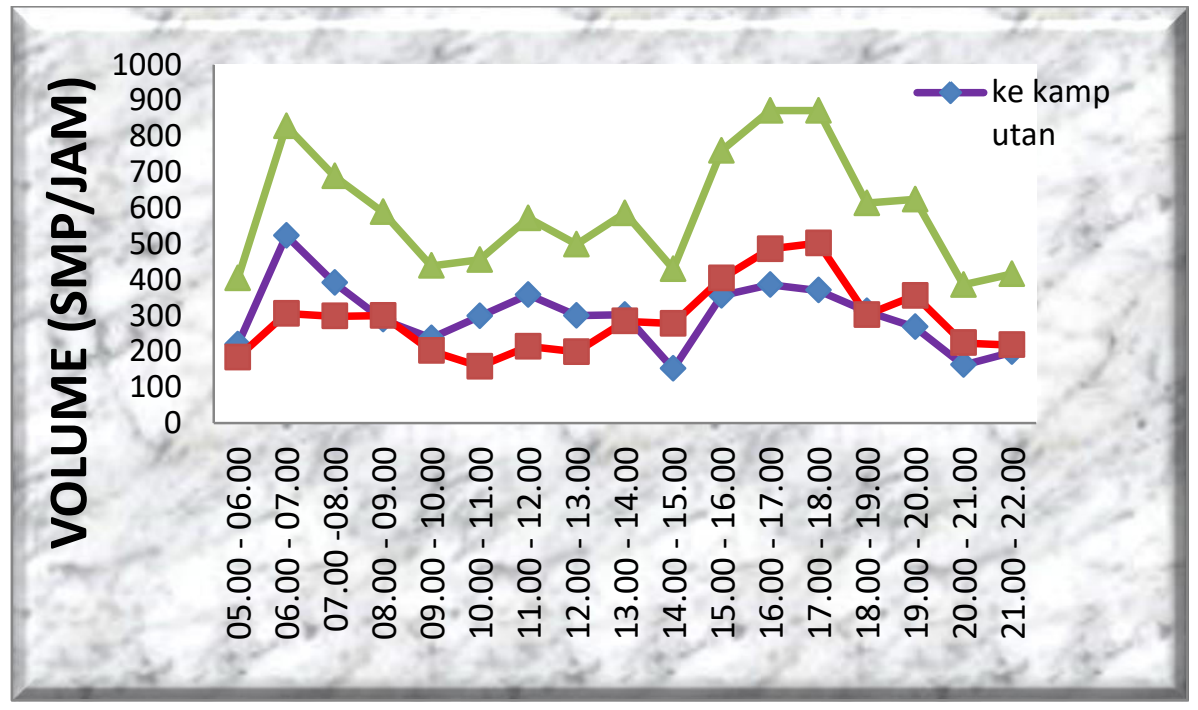

Gambar 4.1. Fluktuasi lalu lintas ruas jalan depan SDN 6 dan 7 


\section{b. Kecepatan ruas jalan}

Kecepatan arus lalu lintas pada ruas jalan raya Kampung Utan - Setu atau depan Sekolah Dasar 6 dan 7 Cibuntu Cibitung Bekasi memiliki kecepatan sekitar 20,88 km/jam sampai 47,40 km/jam. Kecepatan saat menuju lokasi lebih tinggi disbanding pada saat lokasi pada saat pengamatan pada jam 06.00 - 07.00 WIB. Kendaraan yang menuju Kampung Utan (dari Setu) relatif lebih lambat $(29,41 \mathrm{~km} / \mathrm{jam})$ apabila dibanding arah sebaliknya (33.43 km/jam). Pada saat ada aktivitas siswa yang menuju ke sekolah kecepatan kendaraan melambat dari 16,59 $17,71 \mathrm{~km} / \mathrm{jam}$ atau relatif lebih lambat dibanding kecepatan kendaraan sebelum sampai di depan sekolah dasar.

\section{Kecepatan kendaraan di ruas jalan Depan SDN 6 dan 7}

\begin{tabular}{|c|c|c|c|c|c|c|}
\hline \multirow[b]{2}{*}{ KONDISI/ ARAH } & \multirow[b]{2}{*}{$\begin{array}{l}\text { Sepeda } \\
\text { Motor }\end{array}$} & \multicolumn{4}{|c|}{ Kecepatan (km/jam) } & \multirow[b]{2}{*}{$\begin{array}{l}\text { Rata-rata } \\
(\mathrm{km} / \mathrm{jam})\end{array}$} \\
\hline & & Mobil & MPU & Pick Up & $\begin{array}{c}\text { Truk } \\
\text { Sedang }\end{array}$ & \\
\hline $\begin{array}{l}\text { Lokasi depan SD } \\
\text { (Ke Kampung Utan) }\end{array}$ & 30.90 & 15.71 & 10.88 & 20.41 & 5.03 & 16.59 \\
\hline $\begin{array}{l}\text { SEBELUM SD } \\
\text { (Ke Kampung Utan) }\end{array}$ & 38.07 & 30.51 & 25.65 & 29.52 & 23.31 & 29.41 \\
\hline Lokasi depan SD (ke Setu) & 33.40 & 19.46 & 11.87 & 15.65 & 8.15 & 17.71 \\
\hline SEBELUM SD (ke Setu) & 45.23 & 33.62 & 28.17 & 33.71 & 26.42 & 33.43 \\
\hline Jumlah & 36.90 & $\underline{24.83}$ & $\underline{19.14}$ & 24.82 & $\underline{15.73}$ & 24.28 \\
\hline
\end{tabular}

Kecepatan kendaraan rata mencapai $24,28 \mathrm{~km} / \mathrm{jam}$ pada saat melintas ruas jalan sepanjang depan sekolah, hal ini masih relative tinggi dengan konflik yang terjadi antara pergerakan kendaraan dengan orang yang menuju/pulang sekolah.

\section{Proporsi drop offor in siswa}

a. Perjalanan berangkat sekolah (drop off)

Pelaku perjalanan berangkat ke sekolah, bagi siswa yang diantar akan diturunkan diluar area sekolah dan di dalam area sekolah. Kedua jenis pelaku perjalanan dapat menggunakan kendaraan pribadi (sepeda motor), kendaraan umum dan berjalan kaki. Pengguna angkutan umum akan 
menurunkan penumpang (siswa atau siswa dan pengantar) di tepi jalan (area di luar sekolah).

Komposisi perjalanan berangkat sekolah antara yang drop off di luar sekolah dan di dalam sekolah dapat dilihat pada table di bawah ini.

Perjalanan berangkat ke sekolah berdasarkan titikdrop off (pagi hari, 06.00 - 07.00 WI

\begin{tabular}{lc}
\hline di dalam sekolah & 121 \\
\hline di luar sekolah & 69 \\
\hline Total & 190
\end{tabular}

Pelaku perjalanan yang menurunkan siswa di luar area sekolah sebesar 36 $\%$ sedangkan yang diturunkan dalam area sekolah sekitar 64 $\%$.Selangkapnya dapat dilihat pada grafik di bawah ini.

\section{b. Perjalanan pulang sekolah (drop in)}

Pelaku perjalanan pulang ke sekolah, bagi siswa yang diantar akan dijemput diluar area sekolah dan di dalam area sekolah. Kedua jenis pelaku perjalanan dapat menggunakan kendaraan pribadi (sepeda motor), kendaraan umum dan berjalan kaki. Pengguna angkutan umum akan menaikkan penumpang (siswa atau siswa dan pengantar) di tepi jalan (area di luar sekolah).

Komposisi perjalanan berangkat sekolah antara yang drop in di luar sekolah dan di dalam sekolah secara umum dapat disimpulkan banyak di dalam area sekolah, selengkapnya dapat dilihat pada table di bawah ini.

Perjalanan berangkat ke sekolah berdasarkan titikdrop in(siang hari, 11.00 - 12.00 WIB

\begin{tabular}{lc}
\hline di dalam sekolah & 129 \\
\hline di luar sekolah & 76 \\
\hline Total & 205 \\
\hline
\end{tabular}


Pelaku perjalanan yang menaikkan siswa di luar area sekolah sebesar 37 $\%$ sedangkan yang diturunkan dalam area sekolah sekitar 63 $\%$.Selangkapnya dapat dilihat pada grafik di bawah ini.

\section{c. Perjalanan berangkat sekolah (drop off) sesuai jenis moda}

Pelaku perjalanan berangkat sekolah (drop off) terdiri dari perjalanan dengan berjalan kaki, menggunakan angkutan umum sendirian atau didampingi pengantar dan naik sepeda motor. Hasil pengamatan terhadap 166 pengantar dan siswa pengguna sepeda motor terbesar yakni 116 siswa.

Proporsi drop off siswa menuju sekolah dengan berjalan kaki memiliki ratio $2: 3$ antara siswa yang diturunkan di luar area sekolah dibanding yang diturunkan dalam area sekolah. Selengkapnya proporsi diturunkan siswa antara di dalam dengan di luar area sekolah dapat dilihat pada tabel dan gambar di bawah ini.

\section{Tabel 4.6. Perjalanan berangkat ke sekolah berdasarkan titikdrop} off(pagi hari, 06.00 - 07.00 WIB)

\begin{tabular}{lr}
\hline a. siswa menuju sekolah berjalan kaki (siswa) & 6 \\
\hline di dalam sekolah & 9 \\
\hline di luar sekolah & 15 \\
\hline Jumlah & 12 \\
\hline b. siswa menuju sekolah naik angkot (siswa) & 13 \\
\hline di dalam sekolah & 25 \\
\hline di luar sekolah & \\
\hline Jumlah & 103 \\
\hline c. siswa menuju sekolah naik sepeda motor (siswa) & 13 \\
\hline di dalam sekolah & 116 \\
\hline di luar sekolah & \\
\hline Jumlah &
\end{tabular}

\section{d. Perjalanan pulang sekolah (drop in) sesuai jenis moda}

Pelaku perjalanan pulang sekolah (drop in) terdiri dari perjalanan dengan berjalan kaki, menggunakan angkutan umum sendirian atau didampingi 
pengantar dan naik sepeda motor. Hasil pengamatan terhadap 179 pengantar dan siswa pengguna sepeda motor terbesar yakni 134 siswa.

Proporsi drop off siswa menuju sekolah dengan berjalan kaki memiliki ratio 2 : 3 antara siswa yang diturunkan di luar area sekolah dibanding yang diturunkan dalam area sekolah. Selengkapnya proporsi diturunkan siswa antara di dalam dengan di luar area sekolah dapat dilihat pada tabel dan gambar di bawah ini.

Tabel 4.7. Perjalanan pulang ke sekolah berdasarkan titik drop in(siang hari, 11.00 - 12.00 WIB)

\begin{tabular}{lr}
\hline a. siswa menuju sekolah berjalan kaki (siswa) & 7 \\
\hline di dalam sekolah & 11 \\
\hline di luar sekolah & 18 \\
\hline Jumlah & 12 \\
\hline b. siswa menuju sekolah naik angkot (siswa) & 15 \\
\hline di dalam sekolah & 27 \\
\hline di luar sekolah & \\
\hline Jumlah & 108 \\
\hline c. siswa menuju sekolah naik sepeda motor (siswa) & 26 \\
\hline di dalam sekolah & 134 \\
\hline di luar sekolah & \\
\hline Jumlah &
\end{tabular}

\section{A. KESIMPULAN}

1. Sekolah Dasar 6 dan 7 terletak pada Ruas Jalan Raya Setu - Kampung Utan $\mathrm{km}$ 2,5 merupakan sekolah dasar yang menempati pada satu area secara bersama dengan luas $\left(3.562 \mathrm{~m}^{2}+1.500 \mathrm{~m}^{2}\right) 5.062 \mathrm{~m}^{2}$. Penggunaan lahan lahan pada kiri dan kanan ruas jalan ini adalah pemukiman, bengkel, fasilitas olah raga dan perkantoran.

2. Ruas jalan ini merupakan jalan suburban sehingga memiliki pola lalu lintas yang berbeda antar arah, misalnya menuju Kampung Utan pada sore hari lebih tinggi dibanding arah sebaliknya.Proposi penggunaan kendaraan menunjukkan $91 \%$ menggunakan sepeda motor (data dalam bentuk kendaraan/unit), sedang moda lain sisanya.Tertinggi kedua adalah kendaraan 
untuk jenis mobil penumpang (6\%). Pada ruas jalan di depan Sekolah Dasar 6 dan 7 Cibuntu yang menjadi obyek penelitian menunjukan bahwa waktu sibuk pagi terjadi pada 06.00 - 07.00 WIB dan sore hari pada 16.00 - 17.00 WIB. Kondisi lalu lintas yang berhubungan dengan aktivitas sekolah dasar pada waktu 06.00 - 07.00 WIB dan siang hari pada 11.00 - 12.00 WIB menunjukkan bahwa arus lalu lintas mencapai $829 \mathrm{smp} / \mathrm{jam}$ dan $572 \mathrm{smp} / \mathrm{jam}$.

3. Proporsi untuk setiap penggunakan kendaraan dalam perjalanan berangkat sekolah berkisar antara $8-66 \%$, dengan rincian terendah $8 \%$ perjalanan dengan berjalan kaki dan mencapai $66 \%$ menggunakan sepeda motor. Perjalanan pulang sekolah berkisar antara $9-65 \%$, dengan rincian terendah 9 $\%$ perjalanan dengan berjalan kaki dan mencapai $65 \%$ menggunakan sepeda motor

4. Pelaku perjalanan pulang sekolah (drop in) terdiri dari perjalanan dengan berjalan kaki, menggunakan angkutan umum sendirian atau didampingi pengantar dan naik sepeda motor. Hasil pengamatan terhadap 179 pengantar dan siswa pengguna sepeda motor terbesar yakni 134 siswa.

5. Proporsi drop off siswa menuju sekolah dengan berjalan kaki memiliki ratio 2 : 3 antara siswa yang diturunkan di luar area sekolah dibanding yang diturunkan dalam area sekolah. Proporsi menuju sekolah yang diturunkan di luar dan di dalam area sekolah yang mempunyai perbedaan mencolok adalah perjalanan yang naik sepeda motor, perbandingan siswa diturunkan di luar area sekolah mencapai $19 \%$ dan dalam area sekolah $81 \%$.

6. Bangkitan perjalanan dari berbagai asal tempat tinggal siswa mencapai 776 trip/hari dengan pelaku perjalanan tertinggi menggunakan sepeda motor sebesar 582 trip/hari.Perjalanan tertinggi dengan menggunakan sepeda motor untuk mengantar siswa mencapai $75 \%$ dari seluruh perjalanan, $21 \%$ dengan angkutan umum dan $4 \%$ berjalan kaki.

7. Usulan rute pelayanan angkutan antar jemput siswa dengan 2(dua) pelayananyaitu :

- Pelayanan 1 : Kampung Cibuntu Kalimalang - SDN 6/7 Cibuntu PP 
- Pelayanan 2: Kampung Gandasari - Wates - Rawa Banteng Perumahan Hubdat - Cibuntu - SDN 6/7 - PP

Panjang pelayanan angkutan antar jemput siswa dan waktu tempuh masingmasing pelayanan sebagai berikut :

- Pelayanan 1 : panjang rute $500 \mathrm{~m}$, dengan waktu tempuh 1 menit

- Pelayanan 2 : panjang rute 3,1 km dengan waktu tempuh 6 Menit.

8. Rute yang diusulkan adalah gabungan dari kedua pelayanan awal perjalanan dari Cibuntu Kalimalang (600 meter dari Sekolah) - Sekolah Dasar 06 dan 07 - Wates (3,1 km dari Sekolah Dasar) serta dengan waktu operasi mulai 05.00 - 06.55 WIB serta siang hari sekitar jam 12.00 - 13.00 WIB.

9. Biaya antar jemput sebesar Rp 50.000,- per siswa per bulan.

\section{B. SARAN}

1. Perlu dikaji lebih lanjut pola penyelenggaraan angkutan antar jemput dari sisi penyedia jasa untuk memperoleh bentuk pelayanan angkutan yang nyaman, selamat dan teratur.

2. Aspek jaminan keamanan dan keselamatan siswa sebagai pengguna angkutan antar jemput perlu dipertimbangkan termasuk tampilan serta fasilitas yang menarik bagi siswa sesuai usia mereka.

\section{DAFTAR PUSTAKA}

Hobbs, F.D. 1979, Traffic Planning \& Engineering, 2nd Edition, Pergamon International Library, Oxford

Kanafani, A., 1983, Transportation Demand Analysis, McGraw-Hill, New York

Morlok, Edward K., 1984, PengantarTeknikdanPerencanaanTransportasi, 1984, PenerbitErlangga, Jakarta.

Nazir, 1988, MetodePenelitian, Ghalia Indonesia, Jakarta 
Papacostas, C.S. and Prevedouros, P.D., 1993, Transportation Engineering and Planning Second Edition, Prentice Hall.

Norbert Oppenhein, 1995,Urban Travel Demand Modelling, A Wiley-Interscience Publication, Canada

Thagesen, B., 1996, Highway and Traffic Engineering in Developing Countries, Technical University of Demark, E\&FN

Khisty, C.J. and Lall, B.K., 2005. Dasar - DasarRekayasaTransportasi. Jilid 1.EdisiKetiga.Erlangga. Jakarta.

Sugiyono,2007, StatistikUntukPenelitian, Edisikeduabelas, Alfabeta, Bandung.

..........2009, UndangUndangNomor $\quad 22 \quad$ Tahun 2009

TentangLalulintasdanAngkutanJalan,Jakarta.

...........2013, PeraturanPemerintahNomor $79 \quad$ Tahun 2013

TentangJaringanLaluLintasdanAngkutanJalan, Jakarta

,2014, PeraturanPemerintahNomor 74 Tahun 2014 tentangAngkutanJalan, Jakarta

,2016, PeraturanMenteriNomor 16 Tahun 2016 dijelaskanbahwa drop zonel pick up point, Jakarta

1996, KeputusanDirekturJenderalPerhubunganDaratNomor 271 Tahun 1996

tentangPedomanTeknisPerekayasaanTempatPerhentianKendaraanPenump

angUmum, Jakarta 